\title{
STUDIES OF INFLUENZA VIRUS INFECTION IN NEWBORN FERRETS
}

\author{
Madeleine H. Collie, D. I. Rushton, ${ }^{*}$ C. Sweet and H. Smith \\ Department of Microbiology and *Department of Pathology, University of Birmingham, \\ Birmingham B15 2TT
}

\section{Plates XXXVII-XXXVIII}

THE OCCURRENCE of excess infant deaths during influenza epidemics (Dauer and Serfling, 1961; Wynne Griffith et al., 1972) suggests that influenza plays a greater role in infant death and severe illness than is generally recognised (Nelson et al., 1975; Paisley et al., 1978). Although children are highly susceptible to influenza infection, their symptoms may be milder than in the adult (Douglas, 1975). However, convulsions, croup and pneumonia also occur (Brocklebank et al., 1972; Naude et al., 1974; Spence, Brodie and Masson, 1975; Laraya-Cuasay et al., 1977; Paisley et al., 1978). The pathology of influenza in infants has rarely been reported, and then usually in cases complicated by other disease processes (Louria et al., 1959); by contrast, the findings in adult man (Hers and Mulder, 1961) and in the adult ferret (Francis and Stuart-Harris, 1938) have been well described.

Influenza in the healthy adult ferret is a transient, non-fatal illness, similar to that occurring in the vast majority of human adults (Toms et al., 1976). This similarity of clinical and pathological responses in man and ferret, and the recognition of fatal infection in the fetal ferret (Collie et al., 1978) stimulated the present investigation into the susceptibility of the newborn ferret to influenza.

\section{MATERIALS AND METHODS}

Influenza virus. The recombinant virus $\mathrm{A} / \mathrm{PR} / 8 / 34-\mathrm{A} /$ England/939/69 clone $7 \mathrm{a}\left(\mathrm{H}_{3} \mathrm{~N}_{2}\right)$ and the preparation of stock suspensions were described previously (Gould et al., 1972; Sweet, Stephen and Smith, 1974).

Newborn ferrets. Adult ferrets, obtained from A.S. Roe, Little Fakenham, Norfolk, were mated by the method of Sweet, Toms and Smith (1977). Litters were born $42 \pm 1$ days after coitus. Pregnant animals were given wooden litter boxes some days before term and generally the litters were nested in these boxes, out of view and disturbed as little as possible.

Method of infection. The newborn animals were always handled with gloves to avoid the transfer of human odour which might cause rejection by the mother. The inoculum was given intranasally without anaesthetic on the day after birth, either $0.05 \mathrm{ml}$ of phosphate-buffered saline (Dulbecco A) (PBS) or the same volume of saline containing $10^{4 \cdot 9}, 10^{2 \cdot 9}, 10^{1.9}$ or $10^{0.9} 50 \%$ egg-bit infectious doses (EBID50) of clone 7a influenza virus.

Post-mortem studies. (i). Studies of mortality rate and virus isolation were made on 126 
newborn ferrets infected with doses ranging from $10^{4 \cdot 9}$ to $10^{0.9}$ EBID50 of influenza virus and on 93 controls given PBS only. At daily intervals for 9 days after infection, the numbers of live and dead animals were counted in each litter. The dead ferrets were removed and, if decomposition had not progressed too far, they were dissected and tissues were removed for virus titration, as described by Collie et al. (1978); the total quantity of virus in the tissue was calculated and expressed as EBID50. The percentage mortality of 72 newborn ferrets infected with $10^{0.9}$ EBID50 influenza virus and 43 controls was calculated daily from the number of dead animals out of the total number alive on either day 0 (fig. la) or day 3 (fig. 1b). (ii). Histopathological studies were made on ferrets that died, as well as on additional animals that were killed by intraperitoneal injection of 0.3-0.5 ml of Sagatal (May and Baker Ltd, Dagenham) on days 1-9 after infection. In all, 65 infected and 34 control, uninfected ferrets were examined. Dead and killed animals were beheaded, and the intact head and the dissected trachea, bronchi and lungs were fixed in neutral buffered formalin. The heads were subsequently sliced sagitally on either side of the nose and the central block of tissue was sectioned to produce a combined preparation of nasal sinuses, nasal passages, pharynx and upper trachea; the lower trachea was removed from the lungs and sectioned longitudinally; the lungs were blocked out whole and sectioned at several levels. After staining with haematoxylin and eosin, the sections were all examined by the same observer (DIR), who scored the lesions arbitrarily from $\mathrm{O}$ to +++ , indicating a range from normality to severe damage. The nasal sinuses and passages, the trachea, the bronchi and the bronchioles were each scored for surface lesions, cytopathic changes, inflammatory exudate, mucosal vascular engorgement and oedema, epithelial necrosis, epithelial loss and epithelial metaplasia. The contents of the airways were also recorded as proteinaceous fluid, pus, blood and aspirated debris. On the basis of several criteria (vide infra) the lung parenchyma was described as normal or inflamed or as showing non-specific changes.

\section{RESULTS}

\section{Susceptibility of newborn ferrets to influenzal infection}

Preliminary experiments showed that infection with inoculum doses ranging from $10^{4.9}$ to $10^{0.9}$ EBID50 was invariably fatal (table I). However, appreciable numbers $(57 \%)$ of the control animals also died. Further investigations with the lowest dose of virus $\left(10^{0.9}\right.$ EBID50) revealed that most of the

\section{TABLE I}

Number of newborn ferrets surviving intranasal inoculation of various doses of influenza virus or of phosphate-buffered saline (PBS)

\begin{tabular}{|c|c|c|c|c|}
\hline \multirow{3}{*}{$\frac{\begin{array}{c}\text { PBS or the following } \\
\text { doses of influenza virus } \\
\text { (EBID 50) }\end{array}}{\text { Inoculum }}$} & \multirow{2}{*}{\multicolumn{2}{|c|}{$\begin{array}{l}\text { Number of infected } \\
\text { animals alive on }\end{array}$}} & \multirow{2}{*}{\multicolumn{2}{|c|}{$\begin{array}{l}\text { Number of control } \\
\text { animals alive on }\end{array}$}} \\
\hline & & & & \\
\hline & day 0 & day 10 & day 0 & day 10 \\
\hline $\begin{array}{l}10^{4 \cdot 9} \\
10^{2 \cdot .9} \\
10^{1 \cdot 9}\end{array}$ & $\begin{array}{l}21(3)^{*} \\
22(4) \\
11(2)\end{array}$ & $\begin{array}{l}0 \\
1 \dagger \\
0\end{array}$ & $\begin{array}{l}15(2) \\
20(3) \\
15(2)\end{array}$ & $\begin{array}{r}12 \\
11 \\
4\end{array}$ \\
\hline $10^{0.9}$ & $72(11)$ & 0 & $43(9)$ & 13 \\
\hline Total & 126 & $1(0.8 \%)$ & 93 & $40(43 \%)$ \\
\hline
\end{tabular}

* The figure in parenthesis indicates the number of litters used.

$\dagger$ This survivor was born to a mother known to be immune to influenza virus as the result of an earlier experiment. 
control ferrets that died did so during the first few days of the experiment (fig. $1 a$ ). During this time, a similar number of infected ferrets died and these showed only small amounts of virus in their nasal turbinates (fig. 2); in fact, virus was not isolated, even after two passages in eggs, from 12 out of 18 animals dying 1 day after infection, or from eight out of 19 dying 2 days after infection. This suggested that virus infection was not the cause of these early deaths, and that more likely causes were litter disturbance with neglect by the mother or other non-specific, unidentifiable factors. After 4 days, deaths occurred only among the infected ferrets (fig. $1 b$ ) and they had large amounts
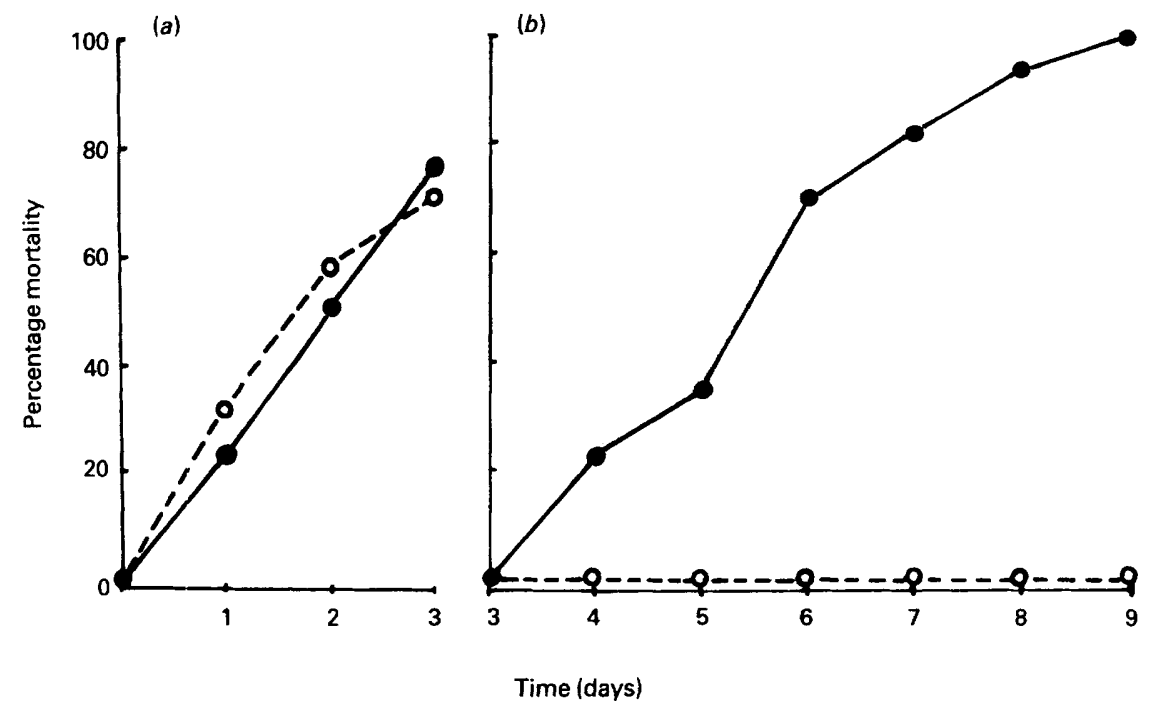

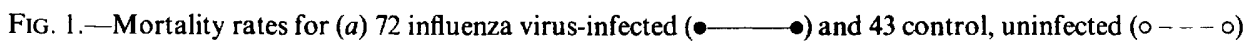
newborn ferrets during the first 3 days after intranasal inoculation of virus or phosphate-buffered saline, respectively, and $(b)$ for the remainder (17 infected and 13 controls) during the subsequent 3-9 days.

of virus (generally $>10^{4}$ EBID50) in the nasal turbinates and in the lungs, especially the latter (fig. 2); virus was also isolated from other parts of the body, most consistently from the intestines and haemopoietic organs, but only at low titre (table II).

\section{Pathological changes in the respiratory tract}

Of the 65 infected newborn ferrets in this part of the study, 29 died and 36 were killed; of the 34 controls, 11 died, all within the first 2 days (table III). Table IV illustrates the distribution of lesions in the respiratory tract of the infected animals. The lesions were essentially focal, and even in the most severely affected animals normal mucosa was commonly found adjacent to damaged epithelium. The table clearly shows the descending nature of the infection.

Surface lesions. Surface epithelial damage was seen only in infected ani- 


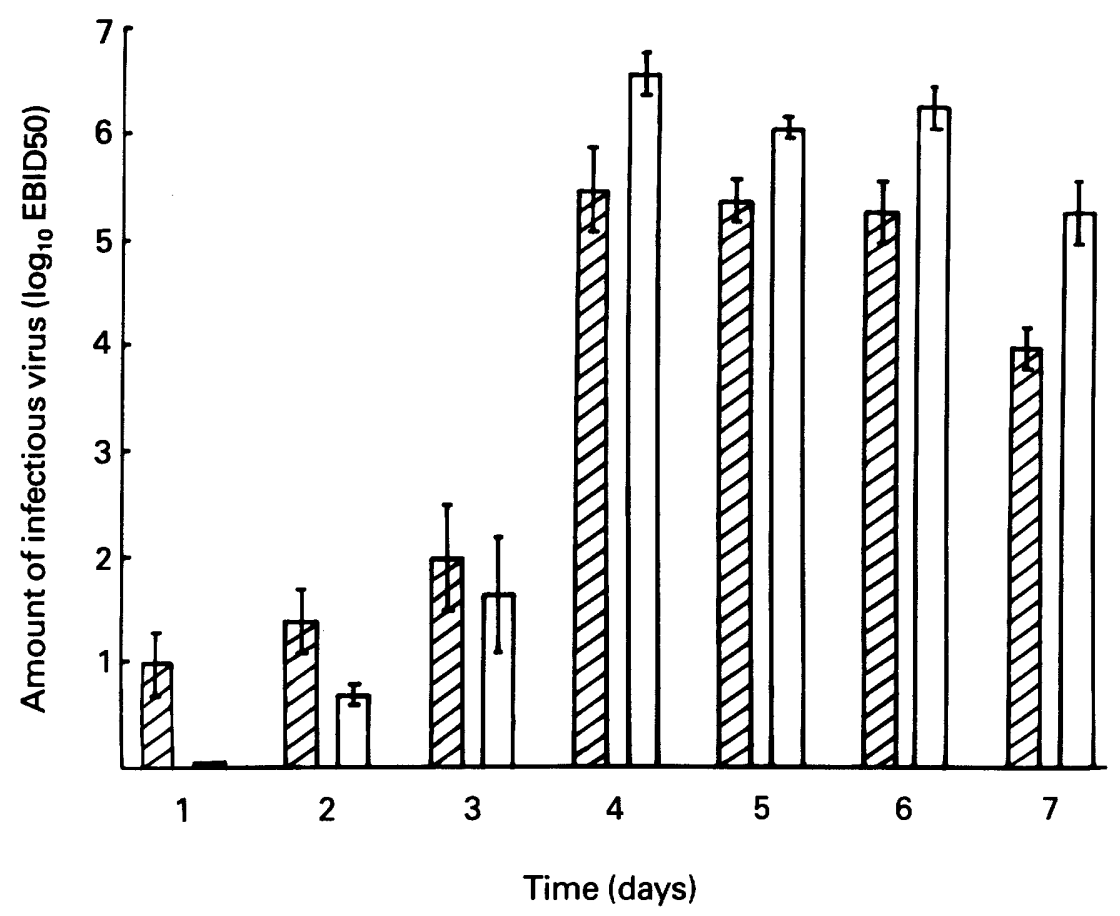

FIG. 2.-Mean quantity of infectious virus (EBID50 \pm standard error) found in the nasal turbinates ( $)$ and lungs (ㅁ) of newborn ferrets dying on days $1-9$ after intranasal infection with $10^{0.9}$ EBID 50 of influenza virus.

mals and was evident within $24 \mathrm{~h}$ of infection. There was irregular loss and retraction of cilia, eosinophilia of the supranuclear cytoplasm and breakdown of the cell surface; the nuclei of the epithelial cells became rounded and hyperchromatic (fig. 3). These changes were best seen in the multilayered epithelium of the nasal sinuses and were absent below the level of the pharynx.

Cytopathic changes were first apparent in infected animals $24-48 \mathrm{~h}$ after infection and were also seen in the nasal sinuses of two control animals, both from the same litter, on days 3 and 4 . The full thickness of the epithelium, with the possible exception of the basal cells, was often involved. There was thickening of the epithelium, loss of polarity of the more superficial cells, nuclear pleomorphism and hyperchromatism, and cytoplasmic swelling that was associated with clear, poorly staining areas of intracellular oedema. Small cysts developed within the epithelium and there appeared to be some disturbance of normal cell adherence (fig. 4); the most superficial cells subsequently underwent necrosis and were shed into the lumen. Goblet-cell enlargement occurred with increased mucin production, and a proteinaceous exudate accumulated in the nasal passages. Reduplication of epithelium was absent or very limited in the trachea and bronchi but individual cells in these passages showed changes similar to those described above.

Vascular engorgement, oedema and polymorph infiltration. An acute inflammatory response was first evident in the mucosa of the nasal sinuses, of 


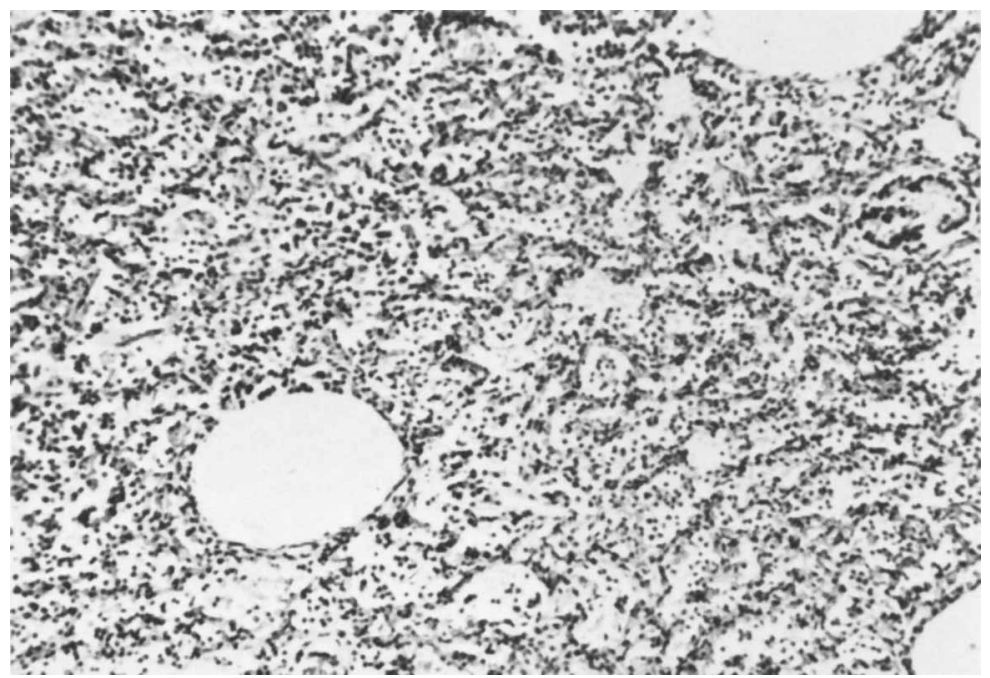

FIG. 3.--Section of nasal sinuses of a newborn ferret killed 3 days after intranasal infection, showing progressive changes from normal ciliated epithelium (on the left) to a typical surface lesion (on the right).

Haematoxylin and eosin $(\mathrm{HE}) . \times 245$.
FIG. 4.-Cytopathic changes in the nasal epithelium of a newborn ferret killed 4 days after infection; abnormal epithelium (above), normal epithelium (below). HE. $\times 245$.

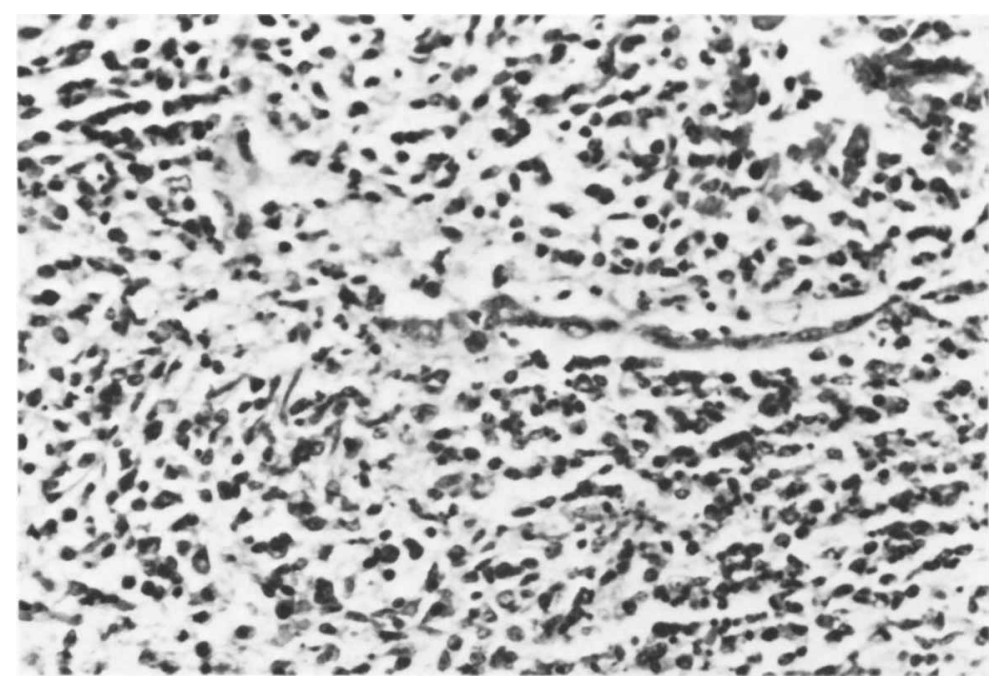

FIG. 5.- Squamous metaplasia in the trachea of a newborn ferret killed 5 days after infection. HE. $\times 245$.
FIG. 6.-Minimal pneumonic changes in a newborn ferret killed 3 days after infection. The alveoli contain a mixture of shed epithelial and alveolar cells with some polymorphs. $\mathrm{HE} \times 245$. 
INFLUENZA VIRUS INFECTION IN NEWBORN FERRETS

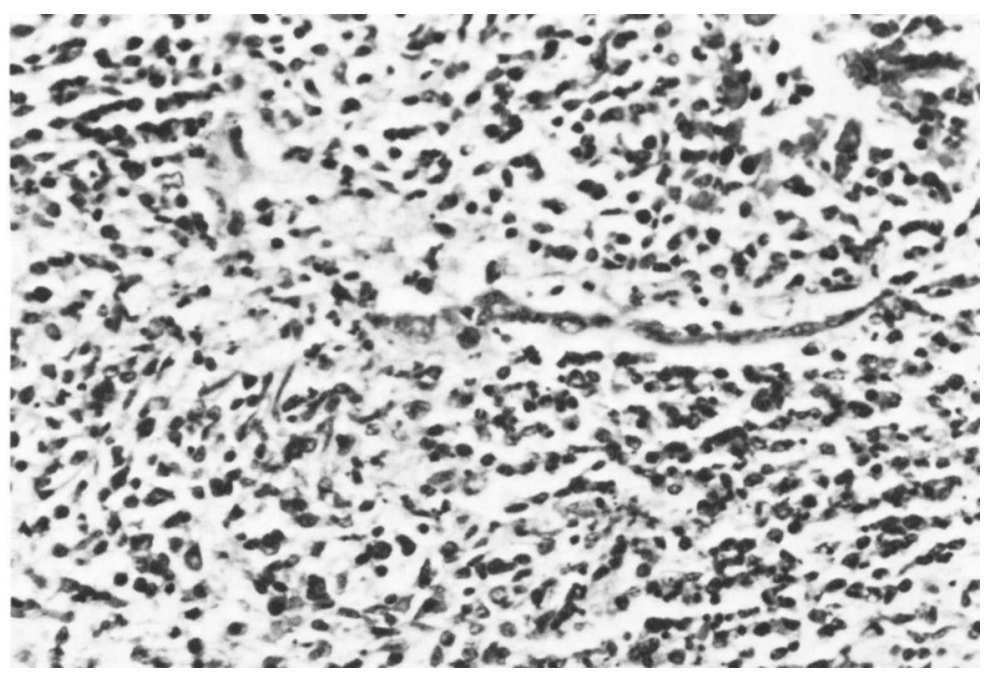

FIG. 7.-Appearances of influenzal pneumonia, with extensive alveolar collapse, in a newborn ferret that died 4 days after infection. HE. $\times 120$.

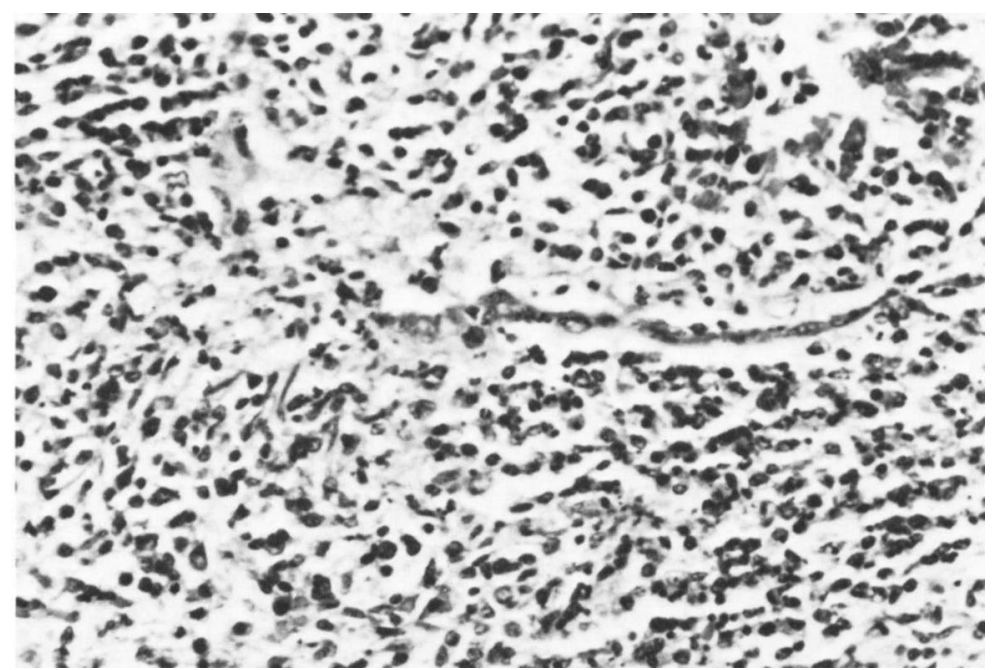

FIG. 8.--Necrotising bronchiolitis in a newborn ferret that died 5 days after infection. The strand of epithelium is the remnant of a bronchiole. HE. $\times 300$. 


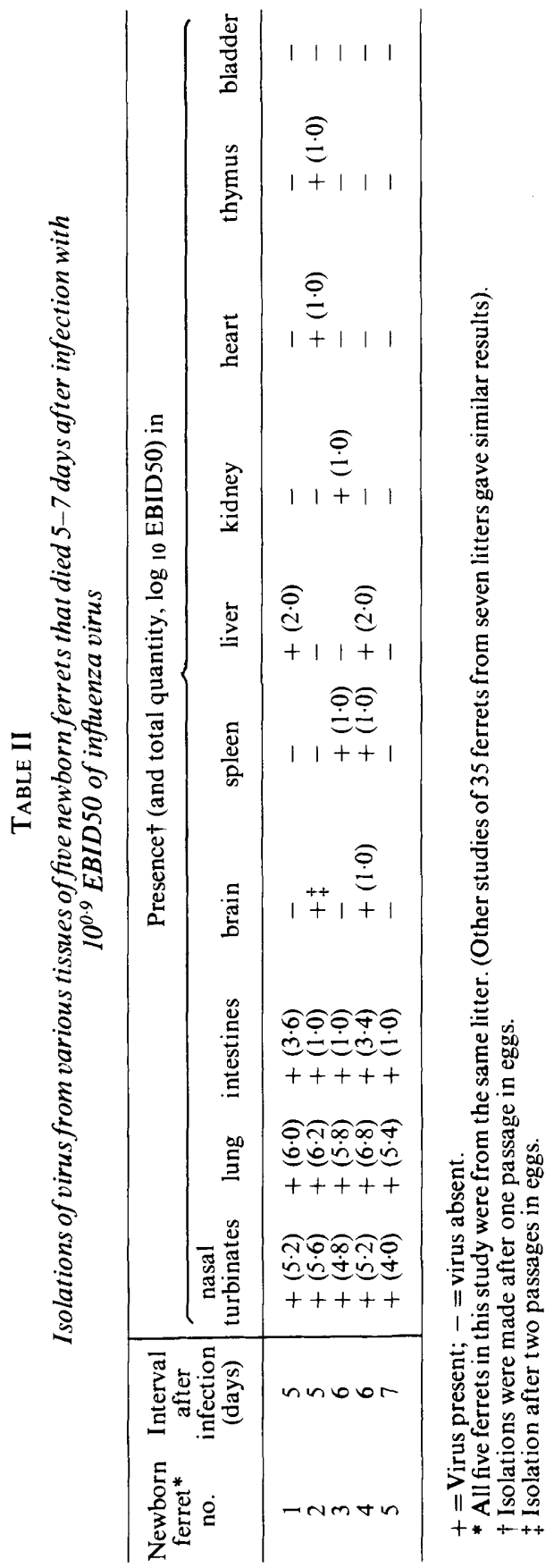


TABLE III

Numbers of influenza virus-infected and control, uninfected newborn ferrets that died or were killed on days 1-9 after inoculation of virus or phosphate-buffered saline

\begin{tabular}{c|ccccc}
\hline $\begin{array}{c}\text { Interval } \\
\text { after } \\
\begin{array}{c}\text { inoculation } \\
\text { (days) }\end{array}\end{array}$ & \multicolumn{4}{|c}{ Number of animals that } \\
\cline { 2 - 5 } Infected & Controls & \multicolumn{3}{c}{ were killed } & Infected Controls \\
\hline 1 & 3 & 8 & 5 & 1 & 17 \\
2 & 3 & 3 & 5 & 4 & 15 \\
3 & 3 & 0 & 6 & 4 & 13 \\
4 & 3 & 0 & 7 & 5 & 15 \\
5 & 5 & 0 & 5 & 3 & 13 \\
6 & 5 & 0 & 3 & 4 & 12 \\
7 & 4 & 0 & 3 & 2 & 9 \\
8 & 2 & 0 & 0 & 0 & 2 \\
9 & 1 & 0 & 2 & 0 & 3 \\
\hline
\end{tabular}

TABLE IV

Distribution of major lesions in the respiratory tract of virus-infected newborn animals* on days 1-9 after infection

\begin{tabular}{|c|c|c|c|c|c|c|c|c|c|}
\hline \multirow{2}{*}{ Tissue } & \multicolumn{9}{|c|}{ Presence of lesions on days } \\
\hline & 1 & 2 & 3 & 4 & 5 & 6 & 7 & 8 & 9 \\
\hline Nasal sinus & - & + & + & + & + & + & + & + & + \\
\hline Nasal passages & - & + & + & + & + & + & + & + & + \\
\hline Trachea & - & - & - & + & + & + & + & + & + \\
\hline Bronchi & - & - & - & - & + & + & + & + & + \\
\hline Bronchioles & - & - & - & - & - & + & + & + & + \\
\hline
\end{tabular}

$+=50 \%$ of animals showing histopathological lesions consistent with influenza; $-=$ no major lesions

* Control, uninfected animals consistently failed to show comparable lesions.

infected animals only, at 24-48 h. During the next 2 days this extended to involve the nasal passages and lower respiratory tract. Initially, oedema, focal haemorrhage and capillary dilatation predominated, with a minimal polymorphonuclear-cell response. Later, pus accumulated in the airways. Vascular engorgement was seen in two control animals, from the same litter, on the first day but this was not associated with an inflammatory cellular response.

Epithelial necrosis and loss was rarely observed in infected ferrets before the 3rd day, but there was extensive necrosis in the sinuses, nasal passages and upper trachea by the 4th day; it was seen in the nasal tract of one control animal that died on the 2 nd day. After loss of the surface epithelium, an attenuated layer of basal cells persisted, often covered by mucopurulent exudate.

Metaplasia. Squamous metaplasia associated with regenerative activity of basal cells was first seen in the upper respiratory tract on day 5 and in the lower respiratory tract on day 6; it was widespread by the 9 th day (fig. 5). Metaplasia was not observed in the control animals. 


\section{TABLE V $a$}

Numbers of newborn ferrets, dying or killed on days 1-9 after intranasal infection with influenza virus, showing various pathological features in the lungs

\begin{tabular}{|c|c|c|c|c|c|c|c|c|c|c|c|c|c|c|c|c|c|c|}
\hline \multirow[b]{2}{*}{ Pathological features } & \multicolumn{18}{|c|}{ Numbers of animals with lesions on day } \\
\hline & $\overbrace{\mathrm{DI}}^{1}$ & $\mathbf{K}$ & $\overbrace{D}^{2}$ & & & & 4 & & D & & $\overbrace{\mathrm{D}}^{6}$ & & D & 7 & 8 & & & $\mathbf{K}$ \\
\hline $\begin{array}{l}\text { None } \\
\text { Congestion } \\
\text { Collapse } \\
\text { Haemorrhage } \\
\text { Oedema } \\
\text { Aspiration } \\
\text { Pneumonia: minimal } \\
\end{array}$ & $\begin{array}{ll}0 & 3 \\
2 & 1 \\
1 & 1 \\
0 & 2 \\
0 & 1 \\
1 & 1 \\
2 & 3 \\
1 & \end{array}$ & $\begin{array}{l}3 \\
1 \\
1 \\
2 \\
0 \\
0 \\
0 \\
0\end{array}$ & $\begin{array}{l}0 \\
3 \\
3 \\
3 \\
0 \\
1 \\
0 \\
3\end{array}$ & $\begin{array}{l}2 \\
1 \\
2 \\
1 \\
0 \\
0 \\
0 \\
0\end{array}$ & $\begin{array}{l}0 \\
1 \\
2 \\
2 \\
0 \\
1 \\
0 \\
2\end{array}$ & $\begin{array}{l}1 \\
0 \\
4 \\
3 \\
1 \\
2 \\
0 \\
2^{*}\end{array}$ & $\begin{array}{l}0 \\
2 \\
3 \\
3 \\
0 \\
2 \\
1^{*} \\
1^{*}\end{array}$ & $\begin{array}{l}4 \\
1 \\
1 \\
2 \\
0 \\
0 \\
0 \\
0\end{array}$ & $\begin{array}{l}0 \\
5 \\
5 \\
2 \\
4 \\
2 \\
3 \\
2\end{array}$ & $\begin{array}{l}3 \\
0 \\
1 \\
1 \\
0 \\
0 \\
0 \\
0\end{array}$ & $\begin{array}{l}0 \\
4 \\
5 \\
5 \\
1 \\
5 \\
0 \\
5^{*}\end{array}$ & $\begin{array}{l}0 \\
0 \\
2 \\
3 \\
0 \\
1 \\
0 \\
1\end{array}$ & $\begin{array}{l}0 \\
4 \\
4 \\
3 \\
2 \\
2 \\
0 \\
2 *\end{array}$ & $\begin{array}{l}1 \\
0 \\
2 \\
2 \\
0 \\
0 \\
0 \\
0 \\
*\end{array}$ & $\begin{array}{l}0 \\
2 \\
2 \\
1 \\
1 \\
2 \\
1 \\
1\end{array}$ & $\begin{array}{l}0 \\
0 \\
0 \\
0 \\
0 \\
0 \\
0 \\
0\end{array}$ & $\begin{array}{l}0 \\
1 \\
1 \\
1 \\
0 \\
1 \\
0 \\
1\end{array}$ & $\begin{array}{l}0 \\
2 \\
2 \\
2 \\
1 \\
2 \\
0 \\
1\end{array}$ \\
\hline $\begin{array}{l}\text { Conclusion } \\
\text { Normal } \\
\text { Non-specific } \\
\text { changes only } \\
\text { Specific lesions } \\
\text { Total number of } \\
\text { animals examined }\end{array}$ & $\begin{array}{l}0 \\
0 \\
3 \\
3\end{array}$ & $\begin{array}{l}3 \\
2 \\
0 \\
5\end{array}$ & $\begin{array}{l}0 \\
0 \\
3\end{array}$ & $\begin{array}{l}3 \\
0 \\
5\end{array}$ & $\begin{array}{l}1 \\
2\end{array}$ & $\begin{array}{l}4 \\
1\end{array}$ & $\begin{array}{l}1 \\
2\end{array}$ & $\begin{array}{l}3 \\
0\end{array}$ & $\begin{array}{l}0 \\
5\end{array}$ & $\begin{array}{l}2 \\
0\end{array}$ & $\begin{array}{l}0 \\
5\end{array}$ & $\begin{array}{l}2 \\
1\end{array}$ & $\begin{array}{l}2 \\
2\end{array}$ & $\begin{array}{l}1 \\
1\end{array}$ & $\begin{array}{l}0 \\
2\end{array}$ & $\begin{array}{l}0 \\
0\end{array}$ & $\begin{array}{l}0 \\
1\end{array}$ & $\begin{array}{l}1 \\
1\end{array}$ \\
\hline
\end{tabular}

$\mathrm{D}=$ Animals dying; $\mathrm{K}=$ animals killed.

* Each asterisk indicates that the number includes one case of aspiration pneumonia.

TABLE V $b$

Numbers of newborn ferrets, dying or killed on days 1-7 after intranasal inoculation of phosphatebuffered saline, showing various pathological features in the lungs

\begin{tabular}{|c|c|c|c|c|c|c|c|c|c|c|c|c|c|c|}
\hline \multirow{3}{*}{$\begin{array}{l}\text { Pathological } \\
\text { feature }\end{array}$} & \multicolumn{14}{|c|}{ Number of animals with lesions on day } \\
\hline & \multicolumn{2}{|r|}{1} & \multicolumn{2}{|c|}{2} & \multicolumn{2}{|c|}{3} & \multicolumn{2}{|c|}{4} & \multicolumn{2}{|c|}{5} & \multicolumn{2}{|c|}{6} & \multicolumn{2}{|c|}{7} \\
\hline & D & $\mathbf{K}$ & D & $\mathbf{K}$ & $\mathrm{D}$ & $\mathbf{K}$ & D & $\mathbf{K}$ & D & $\mathbf{K}$ & $\mathrm{D}$ & $\mathbf{K}$ & $\mathrm{D}$ & K \\
\hline $\begin{array}{l}\text { None } \\
\text { Congestion } \\
\text { Collapse } \\
\text { Haemorrhage } \\
\text { Oedema } \\
\text { Aspiration } \\
\text { Pneumonia: minimal } \\
\quad \text { severe }\end{array}$ & $\begin{array}{l}0 \\
3 \\
7 \\
3 \\
3 \\
0 \\
0 \\
2\end{array}$ & $\begin{array}{l}0 \\
0 \\
0 \\
1 \\
0 \\
0 \\
0 \\
0\end{array}$ & $\begin{array}{l}0 \\
1 \\
3 \\
0 \\
3 \\
1 \\
0 \\
2\end{array}$ & $\begin{array}{l}2 \\
0 \\
2 \\
0 \\
0 \\
0 \\
0 \\
0\end{array}$ & $\begin{array}{l}0 \\
0 \\
0 \\
0 \\
0 \\
0 \\
0 \\
0\end{array}$ & $\begin{array}{l}0 \\
0 \\
2 \\
0 \\
0 \\
0 \\
0 \\
0\end{array}$ & $\begin{array}{l}0 \\
0 \\
0 \\
0 \\
0 \\
0 \\
0 \\
0\end{array}$ & $\begin{array}{l}3 \\
0 \\
0 \\
2 \\
0 \\
0 \\
0 \\
0\end{array}$ & $\begin{array}{l}0 \\
0 \\
0 \\
0 \\
0 \\
0 \\
0 \\
0\end{array}$ & $\begin{array}{l}0 \\
1 \\
1 \\
3 \\
0 \\
0 \\
0 \\
0\end{array}$ & $\begin{array}{l}0 \\
0 \\
0 \\
0 \\
0 \\
0 \\
0 \\
0\end{array}$ & $\begin{array}{l}2 \\
0 \\
1 \\
1 \\
0 \\
0 \\
0 \\
0\end{array}$ & $\begin{array}{l}0 \\
0 \\
0 \\
0 \\
0 \\
0 \\
0 \\
0\end{array}$ & $\begin{array}{l}2 \\
0 \\
0 \\
0 \\
0 \\
0 \\
0 \\
0\end{array}$ \\
\hline $\begin{array}{l}\text { Conclusion } \\
\text { Normal } \\
\text { Non-specific } \\
\text { changes only } \\
\text { Specific lesions } \\
\text { Total number of } \\
\text { animals examined }\end{array}$ & $\begin{array}{l}6 \\
2\end{array}$ & $\begin{array}{l}0 \\
1 \\
0\end{array}$ & $\begin{array}{l}1 \\
2\end{array}$ & $\begin{array}{l}2 \\
2 \\
0 \\
4\end{array}$ & $\begin{array}{l}0 \\
0\end{array}$ & $\begin{array}{l}0 \\
2 \\
0\end{array}$ & $\begin{array}{l}0 \\
0\end{array}$ & $\begin{array}{l}2 \\
0\end{array}$ & $\begin{array}{l}0 \\
0\end{array}$ & $\begin{array}{l}3 \\
0\end{array}$ & $\begin{array}{l}0 \\
0\end{array}$ & $\begin{array}{l}2 \\
0\end{array}$ & $\begin{array}{l}0 \\
0\end{array}$ & $\begin{array}{l}0 \\
0\end{array}$ \\
\hline
\end{tabular}

Abbreviations as in table $\mathrm{Va}$. 
Lesions in the lungs are detailed in tables $\mathrm{V} a$ and $b$. Of the infected animals, 23 died during days 3-9 after infection and none of them had normal lungs; four showed non-specific changes of congestion, haemorrhage and collapse, five had minimal evidence of pneumonia (fig. 6), and 15 had aspirated material in the lungs, consisting of desquamated epithelial cells, effete polymorphs, red cells and cellular debris from the upper respiratory tract. In six of the latter, aspiration resulted in digestion of the lung with an acute inflammatory response, and their deaths were put down to aspiration pneumonia; the other nine had a frank pneumonia that could be ascribed to influenza (fig. 7). Of the 36 infected ferrets that were killed, five had aspirated material in the lungs. However, only one developed aspiration pneumonia while three of them progressed to influenzal pneumonia (table $\mathrm{V} a$ ). One other ferret, that was killed, developed influenzal pneumonia. None of the 65 animals showed inflammatory changes in the alveolar walls or interstitium of the lung (pneumonitis), and hyaline membrane-like lesions were not observed. One animal dying on the 5th day had an atypical reaction, with a predominantly lymphocytic infiltration, possibly due to another infection. One animal dying on day 7 , with aspiration pneumonia, had septic emboli in the brain. Another, dying on day 8 with aspiration pneumonia, had a severe bronchiolitis (fig. 8).

\section{Discussion}

This investigation clearly demonstrated the severity of influenzal infection in newborn ferrets, contrasting with the mild, transient illness that occurs in the adult animal (Toms et al., 1976). Fatal infection followed the administration of virus doses as small as $10^{0.9}$ EBID50, which is about the minimal infectious dose for the adult (Toms et al., 1976). This small inoculum may have failed to infect all the newborn animals, because many of those dying within 3 days had no detectable virus in the nasal turbinates or lungs. Nevertheless, the fact that all the newborns given virus did eventually die suggests either that asynchrony of infection occurred, as has been shown to happen in adult ferrets (Campbell, Sweet and Smith, 1979), or that cross infection occurred among litter mates. On the other hand, the early deaths, which occurred within the first 3 days, were almost certainly not due to influenza because they occurred, with essentially the same frequency, also among the controls. Four of the six ferrets given virus and four of the 11 controls that died early had histologically confirmed pneumonia (table $\mathrm{V} a$ and $b$ ) but only two of these showed any involvement of the upper respiratory tract, and then only below the level of the nasal passages. In none of these animals, therefore, were the lesions consistent with influenza, and their pneumonias are more likely to have been caused by some other, unidentified, pathogen or factor.

Beyond 3 days, deaths occurred only among infected animals, and because these deaths were associated with large amounts of virus in the nasal turbinates and lungs they could be ascribed to influenza. Moreover, 19 of the 23 infected animals dying later than 3 days had pneumonia (table $\mathrm{V} a$ ), demonstrating greater susceptibility of the newborn ferret lung, compared with the adult lung, 
to influenza virus infection. This is supported by results from organ-culture experiments, which have shown that, after infection of lung tissue taken from adult and newborn ferrets, similar total quantities of virus are produced in both cases but the amount released from the tissue is greater in the case of the younger animal, a difference that is lost after 2 weeks of age (Cavanagh et al., 1979). This could mean that virus disseminates more readily in the newborn lung in vivo. Also, the actual structure of the newborn lung may be an important factor in determining its greater susceptibility. In the human newborn infant, the proportion of alveolar cells to ciliated epithelial cells (in the bronchi, bronchioles and alveolar ducts) is relatively low, the adult proportions not being achieved until as late as 11 years of age (Doershuk, Fisher and Matthews, 1975; Dunnill, 1962). Whether ferrets undergo a similar pattern of lung development is not yet known, but this seems likely because it occurs also in rats (Burri, Dbaly and Weibel, 1974). A reduced number of alveoli in the newborn animal would be expected to give increased vulnerability to fatal infection. At the same time, influenza virus has a predilection for growth in ciliated epithelium (Stuart-Harris and Francis, 1938), which probably explains why patients with chronic cardiac disease, whose alveoli become lined with bronchiolar-type columnar or cuboidal epithelium, are more susceptible to influenza (Spencer, 1977). The higher proportion of such epithelium in the newborn lung could account for the results of the organ-culture experiments and be a further contributing factor to the high fatality rate in newborn ferrets.

Although 23 ferrets died 3-9 days after infection, only nine had apparently uncomplicated influenzal pneumonia, and six others had massive aspiration pneumonia. On the other hand, four ferrets had minimal pneumonia and five showed only non-specific changes in the lungs, neither of which were adequate explanations for death. All the animals, however, showed severe involvement of the upper respiratory tract. Smith, Andrewes and Laidlaw (1933) noted difficulties in breathing in adult ferrets after intranasal infection with influenza virus. Newborn ferrets, with much smaller airways, might be expected to suffer even greater difficulties from obstruction secondary to influenzal inflammation, with the possibility of death from asphyxia, even in those animals with minimal involvement of the lower respiratory tract. Undoubtedly, obstruction in the upper respiratory tract will also interfere with feeding, perhaps resulting in aspiration of food into the lungs; this would account for the large number of deaths from aspiration pneumonia.

The above findings may have relevance for human pathology, particularly with regard to the mechanisms of cot deaths. The histopathological changes in the lung in most respiratory viral infections in children are non-specific (Aherne et al., 1970), and in cot deaths are commonly minimal (Tapp, Jones and Tobin, 1975). Moreover, it has long been suspected that obstruction of the upper respiratory tract plays a role in cot deaths (Cross and Lewis, 1971; Swift and Emery, 1973), because a history of preceding snuffles is common and the risk of death appears to be greater when other symptoms of upper respiratory-tract infection, such as cough, are present (Carpenter et al., 1979).

These data emphasise the need for re-evaluation of the role of influenzal 
infection in newborns and infants. Minor lesions of the upper respiratory tract previously ignored as insignificant would account for the high incidence of upper respiratory-tract symptoms in fatal cases, especially if associated with virus isolation.

\section{SUMMARY}

Influenza virus infection by the intranasal route was found to be invariably fatal in newborn ferrets. Some obviously died of influenzal pneumonia; others died of aspiration pneumonia or showed only minimal or non-specific changes in the lungs. All, however, had severe lesions in the upper respiratory tract, and it is suggested that obstruction of airways and oesophageal passages, in combination with feeding difficulties, played a major role in causing death. The relevance of the findings to the pathology of cot deaths in human infants is briefly discussed.

The technical assistance of Mr J. Atkinson and Mrs S. Chalder is gratefully acknowledged. This work was supported by grants from the Leverhulme Foundation and the National Fund for Research into Crippling Diseases.

\section{REFERENCES}

Aherne, W., Bird, T., Court, S. D. M., Gardner, P. A. And McQuillin, J. 1970. Pathological changes in virus infections of the lower respiratory tract in children. J. clin. Path., 23, 7.

Brocklebank, J. T., Court, S. D. M., MCQuillin, J. AND Gardner, P. S. 1972. Influenza A infection in children. Lancet, 2, 497.

Burri, P. H., Dbaly, J. and Weibel, E. R. 1974. The postnatal growth of the rat lung. I. Morphometry. Anat. Rec., 178, 711 .

CAmpbell, D., SweEt, C. AND SMITH, H. 1979. Comparisons of virulence of influenza virus recombinants in ferrets in relation to their behaviour in man and their genetic constitution. J. gen. Virol., 44, 37.

Carpenter, R. G., Gardner, A., Pursall, E., McWeeny, P. M. and Emery, J. L. 1979. Identification of some infants at immediate risk of dying unexpectedly and justifying intensive study. Lancet, $2,343$.

Cavanagh, D., Collie, M. H., Sweet, C. and Smith, H. 1979. Production and release of influenza virus from fresh and maintained organ cultures of ferret neonatal lung. F.E.M.S. Microbiol. Letts., 5, 431.

Collie, M. H., Sweet, C., Cavanagh, D. and Smith, H. 1978. Association of foetal wastage with influenza infection during ferret pregnancy. Br. J. exp. Path., 59, 190.

Cross, K. W. AND LEWIS, S. R. 1971. Upper respiratory obstruction and cot death. Archs Dis. Childh., 46, 211.

Dauer, C. C. ANd Serfling, R. E. 1961. Mortality from influenza 1957-1958 and 1959-1960. Am. Rev. resp. Dis., 83 (supplement, International Conference on Asian Influenza), 15.

Doershuk, C. F., Fisher, B. J. And Matthews, W. 1975. Pulmonary physiology of the young child. In Pulmonary physiology of the fetus, new born and child, edited by E. M. Scarpelli. Lea \& Fibiger: Philadelphia, p. 166.

Douglas, R. G., JR. 1975. Influenza in man. In The influenza viruses and influenza, edited by E. D. Kilbourne. Academic Press: London, p. 395.

DunNill, M. S. 1962. Postnatal growth of the lung. Thorax, 17, 329.

Francis, T. and Stuart-Harris, C. H. 1938. Studies on the nasal histology of epidemic influenza virus infection in the ferret. I. The development and repair of the nasal lesion. $J$. exp. Med., 68, 789. 
Gould, E. A., Ratcliffe, N. A., Basarab, O. and Smith, H. 1972. Studies of the basis of localization of influenza virus in ferret organ cultures. Br. J. exp. Path., 53, 31.

Hers, J. F. Ph. ANd Mulder, J. 1961. Broad aspects of the pathology and pathogenesis of human influenza. Am. Rev. resp. Dis., 83 (supplement, International Conference on Asian Influenza), 84 .

Laraya-Cuasay, L. R., Deforest, A., Huff, D., Lischner, H. and Huang, N. N. 1977. Chronic pulmonary complications of early influenza virus infection in children. Am. Rev. resp. Dis., 116, 617.

Louria, D. B., Blumenfeld, H. L., Ellis, J. T., Kilbourne, E. D. and Rogers, D. E. 1959. Studies on influenza in the pandemic of 1957-1958. II. Pulmonary complications of influenza. J. clin. Invest., 38, 213.

Naude, W. Du T., Klein, M., KeEN, G. A. AND KIPPS, A. 1974. Virus infections in children in a respiratory intensive care unit during an influenza epidemic. S. Afr. med. J., 48, 2543.

Nelson, K. E., Greenberg, M. A., Mufson, M. A. And Moses, V. K. 1975. The sudden infant death syndrome and epidemic viral disease. Am. J. Epidem., 101, 423.

Paisley, J. W., Bruhn, F. W., Lauer, B. A. And McIntosh, K. 1978. Type A2 influenza viral infections in children. Am. J. Dis. Child., 132, 34.

Smith, W., Andrewes, C. H. and Laidlaw, P. P. 1933. A virus obtained from influenza patients. Lancet, 2,66 .

SPENCE, L. P., Brodie, H. R. AND Masson, A. M. 1975. Respiratory virus infections in children hospitalized in Montreal, 1968-1972. Can. J. publ. Hlth, 66, 209.

SPENCER, H. 1977. Pathology of the lung. 3rd ed. Pergamon: Oxford, vol. 1, p. 204.

Stuart-Harris, C. H. AND Francis, T. 1938. Studies on the nasal histology of epidemic influenza virus infection in the ferret. II. The resistance of regenerating respiratory epithelium to reinfection and to physicochemical injury. J. exp. Med., 68, 803.

SweEt, C., StePhEn, J. AND SmITH, H. 1974. The behaviour of antigenically related influenza viruses of differing virulence on disulphide-linked immunosorbents. Immunochemistry, 11, 823.

Sweet, C., Toms, G. L. And Smith, H. 1977. The pregnant ferret as a model for studying the congenital effects of influenza virus infection in utero: infection of foetal tissues in organ culture and in vivo. Br.J. exp. Path., 58, 113.

SwiFT, P. G. F. AND EMERY, J. L. 1973. Clinical observations on response to nasal occlusion in infancy. Archs Dis. Childh., 48, 947.

TAPP, E., JONES, D. M. AND TOBIN, J. O'H. 1975. Interpretation of respiratory tract histology in cot deaths. J. clin. Path., 28, 899.

Toms, G. L., Bird, R. A., Kingsman, S. M., SweEt, C. ANd Smith, H. 1976. The behaviour in ferrets of two closely related clones of influenza virus of differing virulence for man. $B r . J$. exp. Path., 57, 37.

Wynne Griffith, G., Adelstein, A. M., Lambert, P. M. and Weatherall, J. A. C. 1972. Influenza and infant mortality. Br. med.J., 3, 553. 